\title{
Influence of different spacing and cultivars on yield components and biochemical parameters of onion (Allium cepa L.)
}

\author{
Saurabh Kishor, R. B. Ram, M.L. Meena*, Sachin Kishor, D. C. Meena and Anil Kumar \\ Department of Applied Plant Science (Horticulture), Babasaheb Bhimrao Ambedkar University, Vidya Vihar \\ Rae Bareli Road Lucknow (UP), India
}

\begin{abstract}
The investigation was undertaken to determine the effect of spacing and cultivars on economic horticultural traits of onion. In trail different spacing was taken $7.5 \times 10 \mathrm{~cm}, 10 \times 10 \mathrm{~cm}, 12.5 \times 10 \mathrm{~cm}$ and $15 \times 10 \mathrm{~cm}$. Three varieties viz. Agrifound Light Red, NHRDF Red-3 and NHRDF L-28 were used for study. The layout of experimental field was laid down in Factorial Randomized Block Design with 3 replications. It is clearly revealed that the significantly contrary, yield ha ${ }^{-1}$ was the highest $\left(404.14 \mathrm{q} \mathrm{ha}^{-1}\right)$ at closer spacing $(10 \times 10 \mathrm{~cm})$ and the lowest was $\left(362.47 \mathrm{q} \mathrm{ha}^{-1}\right)$ at wider spacing $15 \times 10 \mathrm{~cm}$. The weight of individual bulb of onion $(49.54 \mathrm{~g})$ was increased with the wider spacing $(12.5 \times 10$ $\mathrm{cm})$. The bulb length $(6.63 \mathrm{~cm})$, diameter $(6.97 \mathrm{~cm})$ and number of scale per bulb $(8.00)$ also the same trend in widest spacing $(15 \times 10 \mathrm{~cm})$. The interaction of spacing and different cultivars had influenced significantly on total soluble solids and ascorbic acid of onion bulb. Significant effect was found among the varieties for total soluble solids, ascorbic acid, reducing sugar. Studied highest total soluble solids (13.960Brix), ascorbic acid (10.03), reducing sugar (8.50), non reducing $(9.70 \%)$ and total sugars $(17.70 \%)$ respectively.
\end{abstract}

KEY WORDS: ONION, SPACING, CULTIVARS, GROWTH AND YIELD

ARTICLE INFORMATION:

*Corresponding Author: drmeena1997@gmail.com

Received $1^{\text {st }}$ July, 2017

Accepted after revision $12^{\text {th }}$ Sep, 2017

BBRC Print ISSN: 0974-6455

Online ISSN: 2321-4007 CODEN: USA BBRCBA

;. Thomson Reuters ISI ESC and Crossref Indexed Journal

NAAS Journal Score 2017: 4.31 Cosmos IF: 4.006

- A Society of Science and Nature Publication, 2017. All rights reserved.

Online Contents Available at: http//www.bbrc.in/

DOI: $10.21786 / \mathrm{bbrc} / 10.3 / 13$ 


\section{INTRODUCTION}

Onion is a bulbous herbaceous biennial vegetable crop which belongs to family Alliaceae and widely grown as with cross-pollinated and monocotyledonous behavior having diploid chromosomes 2n=16 (Bassett, 1986). Onion is the most important bulb crop cultivated commercially in most parts of the world. The crop is grown for consumption both in the green states as well as in mature bulbs. It is valued for its bulbs having characteristics odour, flavor, and pungency, which is due to the presence of a volatile oil-allyl-propyl-disulphide, (Kantona et al., 2003 and Habtamu et al., 2016 and Kishor et al., 2017).

Onion is the richest source of flavonoids in the human diet and flavonoid consumption has been associated with a reduced risk of cancer, heart disease and diabetes. In addition it is known for anti bacterial, antiviral, anti-allergenic and anti inflammatory potential. Even though the crop has great contribution both in economic and health issues, its production and productivity is not scaled to the required level. This is because use of appropriate agronomic management practices and improved technology inputs are still not highly used which have undoubted contribution in increasing crop yield potential. One of the important measures to be taken in increasing the productivity of onion is determining spacing for each agro-ecology since full package of information is required for each growing region the country to optimize onion productivity (Gupta, et al., 1994). Proper spacing ensures optimum plant growth through adequate utilization of moisture, light, spacing and nutrients (Zubeldia and Gases, 1977). The control of plant spacing is one of the cultural practices to control bulb size, shape and yield (Geremew et al., 2010). The higher yield and better control of over or under bulb size bulb size could be obtained if plants are grown at optimum density. Total bulb yield can be increased as population density increase (Kantona et al., 2003 and Habtamu et al., 2016 and Kishor et al., 2017).

Several researchers in many countries have shown that varieties and plant spacing had profound effects on the growth and yield of onion (Pandey et al., 1991; Bhonden et al., 1995 and Kumar et al., 1998, Kishor et al., 2017). Considering the above stated situations, the present study was undertaken to determine the effect of spacing on growth and yield of different cultivars of onion under Lucknow conditions (Allium cepa l.).

\section{MATERIAL AND METHODS}

The experiment was conducted at Horticulture Research Farm-II of Babasaheb Bhimrao Ambedkar University, Vidya Vihar Rae Bareli Road Lucknow (UP) during
November 2015 to April 2016 under subtropical condition. The experiment site lies about $26056 \mathrm{~N}$ latitude and 80052 E longitude at an altitude of $111 \mathrm{~m}$ above sea level. The area experiences rainfall that stretches from April to October with the main rainy season from June to early September. The area receives average rainfall between 800-1000 $\mathrm{mm}$ with annual and maximum temperature ranging from 15 to 300C. Three varieties viz. Agrifound Light Red, NHRDF Red-3 and NHRDF L-28 and four plant spacing such as $7.5 \times 10 \mathrm{~cm}, 10 \times 10$ $\mathrm{cm}, 12.5 \times 10 \mathrm{~cm}$ and $15 \times 10 \mathrm{~cm}$ were used for study. The experiment was laid out in Factorial Randomized Block Design (RBD) and replicated in thrice. Standard analytical methods were followed for recording various parameters. The observation was made on the following parameters yield $\mathrm{kg} /$ plot, yield $\mathrm{kg} / \mathrm{ha}$, weight of bulb, bulb length $(\mathrm{cm})$, bulb diameter $(\mathrm{cm})$, number of scale per bulb, total soluble solids (OBrix) was measured with the help of an Erma hand refractometer and were corrected using standard reference table and express in terms of (0Brix) at 200, ascorbic acid (mg/100g) Ascorbic acid content was determined by diluting the known volume of juice with 3\% meta-phosphoric acid and titrating with 2,6- dichlorophenol-indo-phenol solution, reducing sugar (\%), non reducing sugar (\%) and total sugars $(\%)$ were determined by titrating the sample against Fehlings solution using methylene blue as an indicator. All the parameters were collected from five randomly selected plants of each treatment. On set of the Rabi season these healthy bulb uniform shape and size were selected and transplanted well prepared field Statistical analysis of the data obtained in different set of experiments was calculated following the standard procedure as stated by (Panse and Sukhatme, 1989).

\section{RESULT AND DISCUSSION}

\section{YIELD COMPONENTS}

The results obtained during the investigation in respect to yield components parameters viz., yield $\mathrm{kg} / \mathrm{plot}$, yield $\mathrm{kg} / \mathrm{ha}$, weight of bulb, bulb length $(\mathrm{cm})$, bulb diameter (cm), number of scale per bulb, total soluble solids ( ${ }^{\circ}$ Brix), ascorbic acid (mg/100g), reducing sugar (\%), non reducing sugar (\%) and total sugars (\%) Table 1. The interaction effect of spacing and different cultivars had influenced significantly on the parameters. The maximum yield $\left(7.34 \mathrm{~kg} /\right.$ plot and $\left.489.77 \mathrm{q} \mathrm{ha}^{-1}\right)$ was recorded from the variety Agrifound Light Red with spacing $10 \times 10 \mathrm{~cm}$ followed by the variety NHRDF Red-3 $(6.88 \mathrm{~kg} / \mathrm{plot}$ and $458.77 \mathrm{q} \mathrm{ha}^{-1}$ ) with spacing $7.5 \times 10 \mathrm{~cm}$. The minimum yield (4.67 kg/plot and $311.44 \mathrm{q} \mathrm{ha}^{-1}$ ) was recorded from the variety Agrifound Light Red with spacing $12.5 \times 10$ $\mathrm{cm}$. While the heaviest bulb (57.60 g) was recorded from 
the variety NHRDF L-28 with spacing $12.5 \times 10 \mathrm{~cm}$ followed by variety NHRDF L-28 with spacing $15 \times 10 \mathrm{~cm}$ (55.00 g) and lightest bulb was obtained from the variety Agrifound Light Red with $7.5 \times 10 \mathrm{~cm}$. While the biggest bulb diameter $(7.06 \mathrm{~cm})$ was recorded from the variety NHRDF Red-3 with $15 \times 10 \mathrm{~cm}$ followed by the variety Agrifound Light Red with spacing $15 \times 10 \mathrm{~cm}(6.86 \mathrm{~cm})$.

The lowest bulb diameter $(5.01 \mathrm{~cm})$ was recorded from the variety Agrifound Light Red with $7.5 \times 10 \mathrm{~cm}$. While the length of bulb and number of scale per bulb was not significantly influenced by the different spacing and cultivars. However, the highest length of bulb $(6.86 \mathrm{~cm})$ was recorded from the variety Agrifound Light Red with spacing $15 \times 10 \mathrm{~cm}$ followed by variety NHRDF Red-3 with $15 \times 10 \mathrm{~cm} \mathrm{~cm}(6.53 \mathrm{~cm})$ and the lowest bulb length $(4.86$ $\mathrm{cm})$ was recorded from the variety Agrifound Light Red with spacing $7.5 \times 10 \mathrm{~cm}$. Thus, the number of scale per bulb (8.33) was increased from the variety NHRDF L-28 with spacing $15 \times 10 \mathrm{~cm}$ followed by variety Agrifound Light Red with spacing $15 \times 10 \mathrm{~cm}$ (8.00). This is due to proper spacing ensures optimum growth and weight of bulb through adequate utilization of moisture, light, spacing and nutrients (Zubeldia and Gases, 1977 Habtamu et al., 2016 ). These results are conformity with (Kumar et al., 1998), the highest yield with a spacing of $15 \times 10$ $\mathrm{cm}$, (Kantona et al., 2003) and (Khan et al., 2003) total bulb yield can be increased as population density increase and (Gupta and Gaffer, 1980) bulb size and bulb weight decreased with the decrease in spacing (Kishor et al., 2017).

Table 1 indicated that interaction of spacing and different cultivars had influenced significantly on total soluble solids and ascorbic acid of onion bulb. The maximum total soluble solids $\left(13.96^{\circ} \mathrm{Brix}\right)$ were obtained from variety NHRDF Red-3 with spacing $10 \times 10 \mathrm{~cm}$ followed by variety NHRDF L-28 with spacing $7.5 \times 10$ $\mathrm{cm}\left(13.50^{\circ}\right.$ Brix $)$ and minimum $\left(10.66^{\circ}\right.$ Brix $)$ was recorded from variety Agrifound Light Red with spacing $7.5 \times 10$ $\mathrm{cm}$. While ascorbic acid $(9.93 \mathrm{mg} / 100 \mathrm{~g})$ was increased from variety NHRDF RED-3 with spacing $15 \times 10 \mathrm{~cm}$ followed by variety NHRDF RED-3 with spacing 12.5 $\times 10 \mathrm{~cm}(9.20 \mathrm{mg} / 100 \mathrm{~g})$ and minimum (7.43 mg/100g) amount of ascorbic acid was recorded from variety Agrifound Light Red with spacing $7.5 \times 10 \mathrm{~cm}$.

Thus reducing sugar, non reducing sugar and total sugars were not significantly influenced by the different spacing and cultivars interaction. However, the maximum reducing sugar (8.50\%) was recorded from variety NHRDF L-28 with spacing $15 \times 10 \mathrm{~cm}$ followed by variety NHRDF Red-3 with spacing $15 \times 10 \mathrm{~cm}$ (8.23\%) and minimum (5.50\%) was recorded from variety Agrifound Light Red with spacing $7.5 \times 10 \mathrm{~cm}$. While maximum non reducing (9.70\%) and total sugars (17.70\%) were recorded from variety Agrifound Light Red with spacing $15 \times 10 \mathrm{~cm}$ followed by spacing $7.5 \times 10 \mathrm{~cm}$ and $15 \times 10 \mathrm{~cm}$ with variety

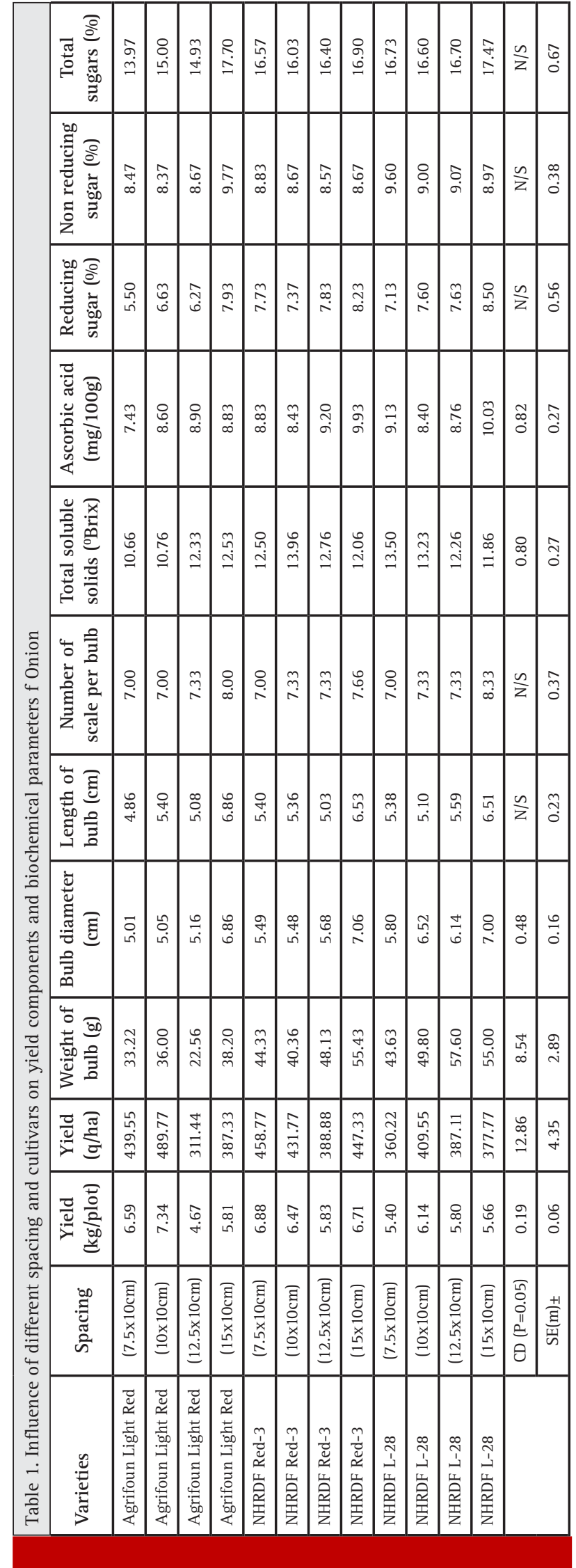

INFLUENCE OF DIFFERENT SPACING AND CULTIVARS ON YIELD COMPONENTS

417 
NHRDF L-28. This result is in agreement with the findings of (Gupta and Gaffer 1980), (Khan et al., 2003) in onion and (Kumar et al., 1998) obtained the better quality with spacing of $15 \times 10 \mathrm{~cm}$ in onion.

\section{CONCLUSION}

Our study was concerted to the combined application of different spacing and varieties favorably influenced plant growth attributes. Results clearly emphasized the importance of spacing as well as selection of varieties of onion, as the conjoint use of them yielded higher and gave a remunerative return. Based on the trend of yield and economical aspects of onion observed in the present study; it was concluded that for getting higher bulb yield of onion, combined application of $10 \times 10 \mathrm{~cm}$ spacing with var. Agrifound Light Red, was best under Lucknow conditions by $7.5 \times 10 \mathrm{~cm}$ spacing with var. NHRDF Red-2 and $15 \times 10 \mathrm{~cm}$ spacing with var. NHRDF Red-2. These results however need to be further confirmed on multi locations large scale trials before passing as recommendations to the onion growers of Lucknow.

\section{ACKNOWLEDGEMENT}

The authors express their thanks to Director, NHRDF Regional Station, Deoria (UP) for providing seed materials.

\section{REFERENCES}

Bassett, M. J (1986) Breeding Vegetable Crops. AVI Publishing Co., USA. 584pp.

Bhonden, S. R., Ram, L., Pandey, U.B. and Tiwari, H.N. (1995). Effect of Micronutrients on Growth, Yield and Quality of Kharif Onion. News lett. National Hort. Res. 14- 15 (1): 16-20.

Geremew, A., Teshome, A., Kasaye, T. and Amenti, C (2010). Effect of Intra-Row Spacing on Yield of Three Onion (Allium
Cepa L.) Varieties at Adami Tulu Agricultural Research Center (Mid Rift Valley Of Ethiopia). J. Hort. For. 2 (1): 7-11.

Gupta and Gaffer (1980). Effect of Row Spacing and Different Combination of NPK Fertilizer on the Yield of Onion. Bangla. Horti. 8: 8-12.

Gupta, R.P., Srivastava, K.J., Pandey, U.B. and Midmore, D.J (1994). Disease and Insect Pest of Onion in India. Acta Hort. 358: 265-372.

Habtamu, T., Minuyelet, J., Esmelealem, M. and Alebachew E. (2016). Influences of Inter and Intra row Spacing on Yield, Yield Component and Morphological Characteristics of Onion (Allium cepa L.) at Western Amhara region. Afr. J. Agric. Res. 11(20):1797-1804

Kantona, R. A. L., Abbeyb, L., Hillac, R.G., Tabil, M.A. and Jane, N.D. (2003). Density Affects Plant Development and Yield of Bulb Onion (Allium Cepa L.) In Northern Ghana. J. Veg. Crop Prod. 8(2):15-25.

Khan, M.A., Hasan, M.K., Miah, M.A.J., Alam, M.M. and Masum, A.S.M.H. (2003). Effect of Plant Spacing on the Growth and Yield of Different Varieties of Onion. Pakistan Journal of Biological Science. 6(18): 1582-1585.

Kishor, S., Ram,R.B., Kishor, S., Meena,M.L. and Satyendra (2017). Effect of Spacing and Different Cultivars on Growth and Yield of Onion Under Lucknow Conditions (Allium Cepa L.). Int.J. Pure App. Biosci. 5(4):612-616. (Online)

Kumar, H., Singh, J.V., Kumar, A. and Singh, M. (1998). Studies on the Effect of Spacing on Growth and Yield of Onion (Allium Cepa L.) Cv. Patnared. Indian J. Agric. Res. 32: 134-138.

Pandey, U. B., Singh, L. Kumar, R., Singh, L., Kumar, R. and Rayehaudhury, S.P. (1991). Response of Different Level of N, P, $\mathrm{K}$ on the Yield And Quality of Kharif Onion. Recent Adv. Med.. Aromat. Et Spice Crops. 1: 231-234.

Panse, V.G. and Sukhatme, P.V. (1989) Statistical Methods for Agriculture Workers. Publication and information division. ICAR, New Delhi.

Zubeldia, A. and Gases, J. L. (1977) Effect of Spacing and the Number of Stem on the Ealiness and Total Yield of Tomato Cultivars. Production Vegetable. 7: 73-97. 